\section{'BRS FS307' high-yielding common bean cultivar with mulatto grain for Northeastern Brazil}

\author{
Luis Cláudio de Faria ${ }^{1 *}$, Helton Santos Pereira ${ }^{1}$, Thiago Lívio \\ Pessoa Oliveira de Souza ${ }^{1}$, Hélio Wilson Lemos de Carvalho ${ }^{2}$, \\ Antônio Félix da Costa ${ }^{3}$, Marcelo Sfeir de Aguiar ${ }^{1}$, Adriane \\ Wendland ${ }^{1}$, José Luis Cabrera Díaz ${ }^{1}$, Joaquim Geraldo Cáprio da \\ Costa $^{1}$ and Leonardo Cunha Melo ${ }^{1}$
}

\begin{abstract}
BRS FS307' is a common bean cultivar with mulatto grain developed for the Northeast of Brazil. Presents the following characteristics: cycle semiearly, yield potential of $4.145 \mathrm{~kg} \mathrm{ha}^{-1}$ and a mean yield of $2.703 \mathrm{~kg} \mathrm{ha}^{-1}$, i.e., $13.9 \%$ higher than that of the control cultivars (BRS Marfim and BRS Agreste).
\end{abstract}

Keywords: Phaseolus vulgaris, breeding, family farming.

\section{INTRODUCTION}

In Brazil, common bean (Phaseolus vulgaris L.) is one of the main agricultural crops (FAO 2019). In the North and Northeast regions, common bean is not only important in economic and agronomic aspects, but also because of its social role, for being cultivated on small farms for subsistence food production, contributing as a basic protein source to food security (Carvalho et al. 2016). Nevertheless, the generation and transfer of technology that could improve common bean production systems, in particular in these regions of Brazil, is precarious. Improved common bean cultivars with high yield, broad adaptation and lower sensitivity to biotic and abiotic stresses represent one of the most significant contributions to the efficiency of this productive sector (Souza et al. 2013). Currently, efforts of common bean breeding in the Northeast Region are being made by Embrapa Rice and Beans, Embrapa Coastal Tablelands and by the Agronomic Institute of Pernambuco (IPA), with activities in the states of Bahia, Sergipe, Alagoas and Pernambuco. With regard to the grain color and type as well as the culinary quality, the regional consumers are demanding. The Northeast is the only Brazilian region where the mulatto grain type is popular. The last mulatto grain cultivars released by Embrapa for the Northeast region were BRS Marfim, in 2002, and BRS Agreste, in 2009. The size and grain quality of CV. BRS FS307 exceed those of cv. BRS Marfim and it produces higher yields than cv. BRS Agreste. Normally, cultivars with this grain type are rather robust, for being adapted to the growth conditions of the region. Thus, during the development of new cultivars by the common bean breeding program of Embrapa Rice and Beans, efforts are being made to take regional demands into consideration.
Crop Breeding and Applied Biotechnology 20(4): e303520410, 2020 Brazilian Society of Plant Breeding. Printed in Brazil http://dx.doi.org/10.1590/198470332020v20n4c63
*Corresponding author: E-mail: luis.faria@embrapa.br (D) ORCID: 0000-0002-3112-0991

Received: 23 Januray 2020 Accepted: 02 August 2020 Published: 30 October 2020

${ }^{1}$ Embrapa Arroz e Feijão, Rod. GO-462, 75.375-000, Santo Antônio de Goiás, GO,

Brazil

2 Embrapa Tabuleiros Costeiros, Av. Beira Mar, Bairro Jardins, 49.025-040, Aracaju, SE, Brazil

${ }^{3}$ Instituto Agronômico de Pernambuco, Av. General San Martin, Bairro Bongi, 50.761-000, Recife, PE, Brazil 


\section{BREEDING METHODS}

BRS FS307 was derived from a cross of the lines CNFM 8080 and BRS Marfim, in 2004, made at Embrapa Rice and Beans, in Santo Antônio de Goiás (GO). In 2004, the $F_{1}$ generation was sown in a greenhouse. In the winter season of 2005, $F_{2}$ bulk seed was sown on the field, in Santo Antônio de Goiás, GO. In the dry season of 2006, the $F_{3}$ generation was bulk-harvested in Ponta Grossa (PR), after selection for plant architecture and resistance to anthracnose, angular leaf spot, rust and common bacterial blight. In the rainy season of 2006, generation $\mathrm{F}_{4}$ was bulk-harvested in Ponta Grossa and selected again for plant architecture and resistance to anthracnose, angular leaf spot, rust and common bacterial blight. In 2007, the $F_{5}$ generation was sown in Santo Antônio de Goiás in the winter, where individual plants were selected for plant architecture.

Also in 2007, the $F_{5: 6}$ generation was sown in the rainy season in Ponta Grossa, where lines were selected for plant architecture and resistance to anthracnose, angular leaf spot, rust and common bacterial blight. In the rainy season of 2008, this line was evaluated in Ponta Grossa for plant architecture and resistance to the same common bean diseases. Thereafter, line CNFM 15642 was evaluated in replicated tests.

In 2010, CNFM 15642 was evaluated in a progeny test with 24 other lines and three controls (BRS Marfim, BRS Agreste and IAC Centauro) in a randomized block design with three replications and two 4-m row plots. The tests were planted in two environments: Ponta Grossa, in the dry season and Santo Antônio de Goiás, in the winter. During these trials, the grain yield, cycle, plant architecture, lodging tolerance and reaction to anthracnose and angular leaf spot were evaluated (Melo 2009).

In 2011, line CNFM 15642 was evaluated in a Preliminary Trial with 12 other lines and three controls (BRS Marfim, BRS Agreste and IAC Centauro), in a randomized block design with three replications and two 4-m row plots. The tests were conducted in four environments: Santo Antônio de Goiás (GO) in the winter; Ponta Grossa (PR) in the rainy and dry season; and Carira (SE) in the rainy season. The grain yield, cycle, plant architecture, lodging tolerance and disease reaction (anthracnose, common bacterial blight, powdery mildew and bacterial wilt) were evaluated.

A combined analysis of preliminary and progeny test data indicated line CNFM 15642 for the VCU (Value for Cultivation and Use) trials. In 2012, the line was multiplied to obtain enough seeds for the VCU tests.

From 2013 to 2015, line CNFM 15642 was evaluated in 22 trials with two control cultivars (BRS Marfim and BRS Agreste), in a randomized block design with three replications and four 4-m row plots, using the recommended technologies for the different environments and cultivation systems. During these trials, the grain yield, crop cycle, plant architecture, lodging tolerance and disease reaction were evaluated. Although the cultivar had its final tests completed in 2015, it cannot be launched this year. As it is a cultivar that is being recommended only for the Northeast region of Brazil, there was great difficulty in the production process of basic seeds and only in the year 2020 was a minimum quantity obtained for its launch.

In the final field trials, environment-specific ANOVAs for seed yield were performed and evaluated with the F-test. These individual analyses addressed the variation between the means and experimental precision of the evaluations in the different environments. The line effect was considered fixed, because the tested elite lines had already been selected for these traits in the preliminary tests and, consequently, no longer represented the original variability. The environmental effect was considered random, because the sampling locations where the field trials were performed represent the normal environmental conditions (locations, growing seasons and years) of common bean seed production in Brazil. Residual variances for the traits were considered non-homogeneous when the ratio between the highest and lowest variances in the individual analyses was >7:1, as suggested by Pimentel-Gomes (2009). In this case, the degrees of freedom of the mean error and genotype - environment (GE) interaction were adjusted as proposed by Cochran (1954). A combined analysis was performed for seed yield and the means were compared by the Scott-Knott test at $5 \%$ probability (Scott and Knott 1974).

\section{GRAIN YIELD AND YIELD POTENTIAL}

From 2013 to 2015, in 22 VCU trials in the rainy season, cultivar BRS FS307 (CNFM 15642) produced mean yields of $2.703 \mathrm{~kg} \mathrm{ha}^{-1}$ (Table 1) in Sergipe, Alagoas, Pernambuco and Bahia, exceeding the mean yield of the control cultivars 
Table 1. Mean seed yield $\left(\mathrm{kg} \mathrm{ha}^{-1}\right)$, agronomical characteristics and disease reactions of cultivar BRS FS307 compared to the control cultivars BRS Marfim and BRS Agreste in final field trials in the northeast of Brazil, from 2013 to 2015

\begin{tabular}{|c|c|c|c|c|c|c|c|c|c|c|c|c|}
\hline Cultivar & YLD* $\left(\mathrm{kg} \mathrm{ha}^{-1}\right)$ & Grain size & Cycle & ARCH & AN & CBB & RU & ALS & CBMV & BGMV & FW & BW \\
\hline BRS FS307 & $2.703 \mathrm{a}$ & MG & SE & SU & MR & $S$ & MR & $S$ & $R$ & $S$ & MR & $S$ \\
\hline BRS Marfim & $2.499 \mathrm{~b}$ & SG & SE & SU & MS & $S$ & MR & $\mathrm{MR}$ & $\mathrm{R}$ & S & MR & $S$ \\
\hline BRS Agreste & $2.320 \mathrm{~b}$ & SG & $\mathrm{N}$ & U & MS & $S$ & MS & $S$ & $\mathrm{R}$ & $S$ & MS & $S$ \\
\hline
\end{tabular}

YLD- Mean grain yield; MG- Medium grain size; SG- small grain size; N- Normal cycle; SE- Semi-early cycle; ARCH- Plant architecture; SE- Semi-upright architecture; U- Upright architecture; AN- Anthracnose (Colletotrichum lindemutianum); CBB- Common bacterial blight (Xanthomonas axonopodis pv. phaseoli and Xanthomonas fuscans pv. fuscans); RU - Rust (Uromyces appendiculatus); ALS- angular leaf spot (Pseudocercospora griseola); CBMV-Common bean mosaic virus; BGMV- Bean golden mosaic virus; FW-Fusarium wilt (Fusarium oxysporum f. sp. phaseoli); BW- Bacterial wilt (Curtobacterium flaccumfaciens pv. flaccumfaciens); R- Resistant; MR- Moderately resistant; MS- Moderately susceptible; S- Susceptible; * Means followed by the same letter are not significantly different by the Scott-Knott test at $5 \%$ probability.

( $2.410 \mathrm{~kg} \mathrm{ha}^{-1}$ ) by $13.9 \%$. In each state separately, the yield was $9.0 \%$ higher in Bahia; $15.2 \%$ in Pernambuco; $12.9 \%$ in Sergipe; and $16.9 \%$ in Alagoas.

The yield potential of 'BRS FS307', averaged across the five trials in which it produced most, was $4.145 \mathrm{~kg} \mathrm{ha}^{-1}$. This estimate demonstrates the high genetic potential of the cultivar and that high yields can be achieved in favorable environments with good cultivation conditions.

\section{ADDITIONAL IMPORTANT AGRONOMICTRAITS}

In terms of the technological and industrial quality traits, the grain color and size of cultivar BRS FS307 are regular and the mean 100-grain weight is 24g, exceeding that of cultivars BRS Marfim (22.8 g) (Del Peloso et al. 2002) and BRS Agreste (21g) (Melo et al. 2008). The mean cooking time of 'BRS FS307' is $43 \mathrm{~min}$ and the mean protein percentage 23\%, which meets the standard for common bean.

Under artificial inoculation, cultivar BRS FS307 is resistant to common mosaic virus. In field evaluations, it was moderately resistant to anthracnose and fusarium wilt. However, it was susceptible to angular leaf spot, bacterial wilt, common bacterial blight and golden mosaic virus (Table 1).

Cultivar BRS FS307 has a semi-early cycle (75 - 84 days from emergence to physiological maturity). The plants have a semi-upright plant architecture, with indeterminate type II growth habit. Lodging tolerance is intermediate and the plants can be harvested mechanically and directly. The semi-early cycle, semi-upright plant architecture and adaptation to mechanical harvesting are important features for producers, for allowing an easy earlier harvesting, be it by hand or machine. The flowers are purple and the physiologically mature pods yellow. At harvest maturity, the pod color is straw yellow. The grains are mulatto, flat and kidney-shaped, not shiny.

The special features of cv. BRS FS307 are mulatto grain and higher yields than those of cultivars BRS Agreste (Melo et al. 2008) and BRS Marfim (Del Peloso et al. 2002), with superior grain quality and moderate resistance to anthracnose and fusarium wilt, which are regionally important diseases. Due to the longer post-harvest shelf-life than that of the common cultivars of the carioca group, cultivar BRS FS307 can be sold at a higher market price, generating higher income for small producers. The release of cultivar BRS FS307 is expected to expand the share of the mulatto grain group on the Brazilian market, to promote common bean cultivation in the Northeast and also to fulfill the mission of the Brazilian Agricultural Research Corporation (Embrapa), of providing technologies for family farming.

The common bean cultivar BRS FS307 with mulatto grain is recommended for the states of Bahia, Sergipe, Alagoas, Pernambuco, Paraiba, Rio Grande do Norte, Ceará and Piauí. It has a semi-early cycle, high yield potential and commercial grain quality, stable yield sand is resistant to anthracnose and fusarium wilt.

\section{SEED PRODUCTION}

Cultivar BRS FS307 was registered (No. 38679) by the Ministry of Agriculture, Livestock and Food Supply (MAPA). Embrapa Rice and Beans, Embrapa Coastal Tablelands and Embrapa Secretariat for Innovation and Business be in charge of the basic seed production. 


\section{LC Faria et al.}

Table 2. Mean seed yield ( $\mathrm{kg} \mathrm{ha}^{-1}$ ) of cultivar BRS FS307 at each test location, compared with the mean of the control cultivars BRS Marfim and BRS Agreste in final field trials in the northeast of Brazil

\begin{tabular}{|c|c|c|c|c|c|}
\hline \multirow{2}{*}{ Locations } & \multirow{2}{*}{ Year } & \multirow{2}{*}{ BRS FS307 } & \multicolumn{2}{|c|}{ Control cultivars } & \multirow{2}{*}{$\begin{array}{l}\text { Percentage of the mean yield of the control culti- } \\
\text { vars }(\%)\end{array}$} \\
\hline & & & BRS Marfim & BRS Agreste & \\
\hline Paripiranga-BA & 2013 & 3.412 & 3.091 & 2.795 & 115.9 \\
\hline Paripiranga-BA & 2014 & 3.367 & 3.542 & 2.889 & 104.7 \\
\hline Paripiranga-BA & 2015 & 3.418 & 2.992 & 3.441 & 106.3 \\
\hline Araripina-PE & 2014 & 854 & 594 & 736 & 128.4 \\
\hline Arco Verde-PE & 2013 & 4.409 & 3.850 & 3.375 & 122.0 \\
\hline Belém de São Francisco-PE & 2014 & 1.659 & 1.339 & 1.324 & 124.6 \\
\hline Belém de São Francisco-PE & 2014 & 1.602 & 1.498 & 1.633 & 102.3 \\
\hline Belém de São Francisco-PE & 2015 & 2.273 & 1.710 & 2.138 & 118.1 \\
\hline Caruaru-PE & 2013 & 2.532 & 2.360 & 2.101 & 113.5 \\
\hline Caruaru-PE & 2014 & 1.294 & 1.320 & 1.104 & 106.8 \\
\hline São João-PE & 2015 & 2.733 & 2.462 & 2.031 & 121.7 \\
\hline Carira-SE & 2013 & 3.550 & 3.229 & 2.304 & 128.3 \\
\hline Carira-SE & 2014 & 4.154 & 4.084 & 3.458 & 110.2 \\
\hline Carira-SE & 2015 & 4.611 & 3.507 & 4.077 & 121.6 \\
\hline Frei Paulo-SE & 2014 & 3.353 & 3.431 & 3.341 & 99.0 \\
\hline Frei Paulo-SE & 2015 & 4.004 & 4.038 & 3.571 & 105.2 \\
\hline Santana do Ipanema-AL & 2015 & 428 & 382 & 350 & 116.9 \\
\hline Overall mean & & 2.703 & 2.499 & 2.320 & 113.9 \\
\hline
\end{tabular}

\section{CONCLUSIONS}

Common bean cultivar BRS FS307 is recommended for Northeastern Brazil and has a semi-early cycle, high yield potential and good commercial grain quality, yield stability, anthracnose resistance and fusarium wilt resistance.

\section{ACKNOWLEDGMENTS}

The following partner institutions contributed to the evaluation of cultivar BRS FS307: Embrapa Rice and Beans, Embrapa Coastal Tablelands, Embrapa Secretariat for Innovation and Business, Agronomic Institute of Pernambuco and Emater Alagoas.

\section{REFERENCES}

Carvalho HWL, Faria LC, Melo LC, Pereira HS, Souza TLPO, Rabelo RR, Almeida EH, Ferreira FMB, Marques MG and Porto ES (2016) Recomendação de cultivares de feijoeiro-comum para o agreste e o sertão dos estados da Bahia, Sergipe e Alagoas. Embrapa Tabuleiros Costeiros, Aracaju, 6p. (Comunicado Técnico, 187).

Cochran WG (1954) The combination of estimates from different experiments. Biometrics 10: 101- 129.

Del Peloso MJ, Faria LC, Costa JGC, Rava CA, Carneiro GES, Soares DM, Cabrera Diaz JL, Sartorato A and Faria JC (2002) BRS Marfim: nova cultivar de feijoeiro comum com tipo de grão mulatinho. Embrapa Arroz e Feijão, Santo Antônio de Goiás, 2p. (Comunicado Técnico, 48).
FAO (2019) Faostat. Available at <http://faostat3.fao.org/browse/Q/QC/ E>. Accessed on February 19, 2019.

Melo LC (2009) Procedimentos para condução de experimentos de valor de cultivo e uso em feijoeiro comum. Embrapa Arroz e Feijão, Santo Antônio de Goiás, 104p. (Documentos, 239).

Melo LC, Costa JGC, Del Peloso MJ, Faria LC, Cabrera Diaz JL, Carvalho HWL, Warwick DRN, Rava CA, Pereira HS, Silva HT, Sartorato A, Faria JC, Bassinello PZ and Wendland A (2008) BRS Agreste - cultivar de feijoeiro comum de grão mulatinho com alto potencial produtivo e porte ereto. Embrapa Arroz e Feijão, Santo Antônio de Goiás, 2p. (Comunicado Técnico, 155).

Pimentel-Gomes F (2009) Curso de estatística experimental. Escola Superior de Agricultura "Luiz de Queiroz", Piracicaba, 451p. 
'BRS FS307' high-yielding common bean cultivar with mulatto grain for Northeastern Brazil

Scott AJ and Knott M (1974) A cluster analysis method for grouping means in the analysis of variance. Biometrics 30: 507-512.

Souza TLPO, Pereira HS, Faria LC, Wendland A, Costa JGC, Abreu AFB,
Cabrera Diaz JL, Magaldi MCS, Souza NP, Del Peloso MJ and Melo LC (2013) Cultivares de feijão comum da Embrapa e parceiros disponíveis para 2013. Embrapa Arroz e Feijão, Santo Antônio de Goiás, 6p. (Comunicado técnico, 211). 